\title{
The influence of sodium on pathophysiology of multiple sclerosis
}

\author{
Jacek Zostawa $^{1} \cdot$ Jowita Adamczyk $^{1} \cdot$ Paweł Sowa $^{2} \cdot$ Monika Adamczyk-Sowa $^{1}$
}

Received: 7 August 2016/Accepted: 19 December 2016/Published online: 11 January 2017

(C) The Author(s) 2017. This article is published with open access at Springerlink.com

\begin{abstract}
Multiple sclerosis (MS) is a chronic, inflammatory, autoimmune disease of the central nervous system, and is an important cause of disability in young adults. In genetically susceptible individuals, several environmental factors may play a partial role in the pathogenesis of MS. Some studies suggests that high-salt diet ( $>5$ g/day) may contribute to the MS and other autoimmune disease development through the induction of pathogenic Th17 cells and pro-inflammatory cytokines in both humans and mice. However, the precise mechanisms of pro-inflammatory effect of sodium chloride intake are not yet explained. The purpose of this review was to discuss the present state of knowledge on the potential role of environmental and dietary factors, particularly sodium chloride on the development and course of MS.
\end{abstract}

Keywords Sodium chloride intake Multiple sclerosis · Environmental factors in MS · VGSCs

\section{Introduction}

Multiple sclerosis (MS) is a chronic, inflammatory, autoimmune disease of the central nervous system (CNS), and is a major cause of disability in young adults [1]. In genetically susceptible individuals, environmental factors

Jowita Adamczyk

jowitkaa@gmail.com

1 Department of Neurology in Zabrze, Medical University of Silesia, ul. 3-go Maja 13-15, 41-800 Zabrze, Poland

2 Department of Otorhinolaryngology and Oncological Laryngology, Medical University of Silesia, ul. C. Skłodowskiej 10, 41-800 Zabrze, Poland play a significant partial role in the pathogenesis of MS [2]. Numerous studies examined the influence of environmental factors, such as Epstein-Barr infection [3-5], vitamin D levels [6-11], smoking [12, 13], obesity [14], sunlight exposure [15, 16], and geographic variation, on MS $[17,18]$.

\section{Methodology}

All quotable references were searched using Pubmed and Google scholar between March and May 2016. References that allowed free access to full text by the Medical University of Silesia were retrieved and read. The oldest publications were retrieved from the Medical University of Silesia Library. One reviewer performed literature searches and two other researchers independently screened the articles. All disagreements were discussed and resolved by the authors or in consultation with other experts. Information used in our review was evaluated using evidencebased medicine. Inclusion criteria for the articles were: original papers, systematic reviews, systematic summaries, and meta-analysis. We excluded publications written in foreign languages, such as Spanish, German, or Russian. Keywords used for literature searches were as follows: "multiple sclerosis", "MS", "sodium", "sodium chloride", "autoimmunity", "diet", and "VGSCs". All keywords were in accordance with the MeSH terms. To identify the appropriate publications, we searched Pubmed and Google scholar using combinations of keywords in the following order: "MS and diet", "MS and salt intake", "MS and environmental factors," and "MS and VGSCs". After reading titles and abstracts, some articles from each combination of keywords were excluded. Most of the excluded articles were in a foreign language. The 
comprehensive literature search identified 907 articles that were relevant for our review. Titles, abstracts, or full articles were reviewed to determine whether each search result matched our selection criteria. We also reviewed the references of the selected original papers and review articles found by our search for additional papers relevant to our review. Only high-quality publications from the last decades were included. In addition, 306 articles were retrieved from the Medical University of Silesia Library. Of these 306 articles, we eliminated those that were too general in scope for our review.

\section{Environmental factors influencing MS}

Although some studies confirmed the link between a previous infection with Epstein-Barr virus (EBV) and the development of multiple sclerosis [3-5, 19-21], the involvement of EBV in the etiology of MS is unclear. However, certain viral infections likely increase susceptibility to MS [22]. Sero-epidemiological studies have demonstrated that almost $100 \%$ of adult MS patients are infected with EBV [19]. Late childhood infection of $\mathrm{EBV}$ is proposed to be the serious risk factor for the disease. Moreover, there is a strong EBV-specific CD8+ response in the blood of MS patients in the beginning of the disease and the intensity decreases in the course of the illness [2-5, 19, 20].

Low serum vitamin D levels are currently one of the most studied environmental factors influencing the development of MS. It has been shown that intake of food rich in vitamin $\mathrm{D}$ significantly prevents the development of MS or reduce activity of the disease [6-9, 16]. Nevertheless, some authors did not report a protective role of vitamin D supplementation for the development of MS $[9,10]$.

Smoking is another possible factor for the development of MS or might be responsible for worst prognosis of course of the disease $[13,23]$. Furthermore, smoking cessation improved the prognosis in patients with MS. Ramanujam et al. confirmed that the time to conversion to secondary progressive MS (SPMS) decreases by $4.7 \%$ for each additional year of smoking after the diagnosis in patients with RRMS (acceleration factor 1.047; 95\% CI 1.023-1.072; $P<0.01$ ) [13].

Obesity is a probable susceptibility factor for MS and several other autoimmune diseases [24], but the relationship between increased body mass index (BMI) and disease activity has not been fully explained. There is no doubt that obesity increases levels of pro-inflammatory cytokines and is associated with low-grade inflammatory state [25]. There are reports providing that RRMS activity is higher in obese and overweight patients than in patients with normal BMI undergoing IFN $\beta$ treatment [14]. Moreover, Oliveira et al. reported a positive relationship between elevated BMI and disability in MS patients [26].

Ultraviolet radiation was proposed to be a significant environmental factor influencing prevalence of the disease [15]. Reduced risk of MS through exposure to sunlight is probably mediated not only by increased production of vitamin $\mathrm{D}$ in the skin, but also by the synthesis of antiinflammatory factors, such as IL-10, TNF- $\alpha$, and Treg cells [16]. Therefore, the latitude is nowadays considered to be related with prevalence of MS. The disease is less frequent near the equator and more frequent in northern countries $[18,27]$. Exceptions to this trend, namely, Sardinia, where the prevalence of the disease is significantly higher [28], and northern Scandinavia, with markedly low prevalence [29], may be due to genetic and behavioral factors [18].

\section{Influence of diet on MS}

It seems that diet might have a significant relationship with the inflammatory process of MS. Many studies have shown that diet plays the role in the pathogenesis of MS [17, 30-32]. Recent studies have provided the evidence for a protective role of polyunsaturated fatty acids on the risk of MS; however, there is no conclusive evidence for a beneficial role of polyunsaturated fatty acid supplementation in patients with MS. Hoare et al. demonstrated that the amount of omega-3 polyunsaturated fatty acids taken orally is inversely proportional to the risk of demyelination in the CNS [33]. Moreover, Khalili et al. found a strong correlation between oral intake of lipoic acid ( $1.2 \mathrm{mg} /$ day) and decrease in the levels of pro-inflammatory cytokines, including INF- $\gamma$, ICAM-1, and anti-inflammatory cytokines, including TGF- $\beta$ and IL-4, compared with placebo group [35]. On the other hand, Torkildsen et al. showed that consumption of omega-3 fatty acids used as monotherapy or in combination with interferon beta-1a had no beneficial effect on the disease compared to placebo [34]. Retinoic acid (RA), an active metabolite of vitamin A, revealed a strong immunosuppressive activity [36]. RA has been shown to modulate the balance between Th1/Th2 and Th17/Treg cells and B cell function, contributing to augmented tolerance and inhibited inflammatory response. It also contributes to enhanced tolerance and reduction of inflammatory effects [37]. Bitarafan et al. investigated the impact of vitamin A on disease progression in MS patients. The study evaluated the expanded disability status scale (EDSS) and MS functional composite (MSFC). The results showed that vitamin A improved MSFC in RRMS patients, but did not affect EDSS, relapse rate, or active brain lesions in MRI [38]. Ketogenic diet (high amount of fat, decreased protein content, and very low carbohydrates) was shown as potentially therapeutic in progressive forms of MS, which 
is especially relevant, because currently, there is no treatment for progressive forms of the disease [39, 40]. Kim et al. reported that ketogenic diet improved motor disability and cognitive impairment in mice with experimental autoimmune encephalomyelitis compared with mice on the standard diet. Furthermore, a ketogenic diet reversed structural brain lesions and reduced CNS inflammation and oxidative stress [41]. On the other hand, it was reported that creatine supplementation did not improve muscle capacity or habitual fatigue in MS individuals [42] or that restricted intake of animal fat (no more than 10-15 g/day) caused remission of the disease in patients with RRMS [43].

Polyphenols and carotenoids from vegetables, n-3 PUFA from fish, vitamins A, C, D, and E, thiol compounds, such as lipoic acid, and oligoelements, such as selenium and magnesium, have anti-oxidant properties [44, 45]. Th17 cells, which produce pro-inflammatory cytokines, are increased, whereas Treg cells are decreased in MS, and thus, the balance between Th17 and Treg cells is impaired in this disease. Vitamin A and its active metabolites (alltrans-retinoic acid and 9-cis-retinoic acid) modulate the imbalance of Th17 and Treg cells and might be beneficial to the prevention and treatment of MS [46]. Moreover, this vitamin was proposed to have a beneficial effect during interferon therapy and improved psychiatric outcomes for anti-inflammatory mechanisms [37].

\section{Sodium channels in MS}

Voltage-gated sodium channels (VGSCs) are key mediators of action potential initiation and propagation in excitable cells [47-49]. Their expression has also been reported in cell types that are traditionally regarded as nonexcitable, including glia, human vascular endothelial cells, human epidermal keratinocytes, and carcinoma cells, where their role is less clear [50-55]. Aberrant functional expression/activity of VGSCs has been identified as a major contributing factor in a number of human pathologies, including cardiac arrhythmia [55], epilepsy [56, 57, 58], pain [59, 60], periodic paralysis [61, 62], migraine [63], MS [64], and cancer [65]. VGSCs exist as heteromeric membrane-bound protein complexes that typically consist of a single pore-forming $\alpha$ subunit in association with one or more $\beta$ subunits [66, 67].

The mammalian sodium channels include ten members (Nav1.1-Nav1.9 and Nax) encoded by genes SCN1ASCN11A. While substantial homology exists between the isoforms, differences in amino acid sequence confer distinct voltage dependence, kinetic and pharmacological properties on each of the isotypes [68, 69]. Data concerning the location and function of each VGSCs subunit are included in Table 1.

$\beta$ subunits ( $\beta 1-\beta 4$ ) combine in vivo with either $\beta 1$ or $\beta 3$ through non-covalent bonding and with either $\beta 2$ or $\beta 4$ via a covalent bond [101-104]. Numerous studies have revealed the presence of $\mathrm{Na}_{\mathrm{v}} 1.1, \mathrm{Na}_{\mathrm{v}} 1.2, \mathrm{Na}_{\mathrm{v}} 1.3$ [105], $\mathrm{Na}_{\mathrm{v}} 1.6$ [106], and $\mathrm{Na}_{\mathrm{v}} 1.5$ [107] in rodent astrocytes. Sodium channels in these glial cells are localized to the plasma membrane, where they mediate sodium currents [108]. The star-shaped glial cells situated in the CNS take an essential part in the response of the CNS to injury, including inflammation and degeneration in MS. Herzog et al. have shown that VGSCs can contribute to axonal injury in MS by providing a pathway for sustained sodium influx that drives the $\mathrm{Na}^{+} / \mathrm{Ca}^{2+}$ exchanger to import calcium into axons [109]. Elevated calcium levels can activate nitric oxide synthase and deleterious proteolytic enzymes [109-112]. The harmful effects of nitric oxide on mitochondrial function include a reduction in adenosine triphosphate (ATP) levels and an exhaustion of sodiumpotassium adenosine triphosphatase $\left(\mathrm{Na}^{+} \mathrm{K}^{+}\right.$-ATPase $)$, hence compromising the axons' capacity to maintain normal transmembrane sodium gradient. This action provides a positive feedback loop that imports even more intracellular calcium, thereby further enhancing the damage [113]. Consequently, these mechanisms lead to axonal injury and further to disability (Fig. 1).

Numerous studies have shown that partial blockade of voltage-gated sodium channels could result in neuroprotection in patients with MS [112]. Indeed, the axonal protection has been demonstrated in animals with experimental autoimmune encephalomyelitis (EAE) by means of the sodium channel blocking drugs flecainide [114, 115], safinamide [115], phenytoin [116], and, recently, lamotrigine [117]. Neuroprotection is emerging as a potentially important strategy for preventing disability progression in MS [118]. In contrast, some clinical studies do not support the protective role of VGSC blockers in MS. Counihan et al. studied 400 patients, 51 of whom received CBZ symptomatic therapy (average duration of therapy was 27 months), and showed that the long term exposure to the VGSC-blocking drug CBZ does not affect the long-term disability and disease progression in MS patients, despite studies in animals suggesting a neuroprotective role of VGSC blockers [119]. Furthermore, using CSF neurofilament $(\mathrm{NfH})$ as a good surrogate marker of neurodegeneration in MS, Gnanapavan et al. revealed no benefit of lamotrigine in the prevention of axonal breakdown by lowering $\mathrm{NfH}$ levels compared to the placebo arm [120]. The protective role of lamotrigine is also disputed by Kapoor et al. [121], but it is premature to fully dismiss this hypothesis. 
Table 1 Voltage-gated sodium channels (VGSCs)

\begin{tabular}{|c|c|c|c|}
\hline Protein & Human gene & Location & Function \\
\hline \multicolumn{4}{|c|}{ (A) The $\alpha$ subunits } \\
\hline $\mathrm{Na}_{\mathrm{v}} 1.1$ & SCN1A & CNS, PNS, heart & CBH, dementia [70], Dravet syndrome [71], epilepsy [71, 72] \\
\hline $\mathrm{Na}_{\mathrm{v}} 1.2$ & $S C N 2 A$ & CNS, PNS & $\mathrm{CBH}$, dementia [70], epilepsy [73, 74], autism [74] \\
\hline $\mathrm{Na}_{\mathrm{v}} 1.3$ & $S C N 3 A$ & CNS, PNS & Diabetes [75], neuropathic pain [76-78] \\
\hline $\mathrm{Na}_{\mathrm{v}} 1.4$ & $S C N 4 A$ & Skeletal muscle, heart & Brugada syndrome [79], myotonia, periodic paralysis [80] \\
\hline $\mathrm{Na}_{\mathrm{v}} 1.5$ & $S C N 5 A$ & $\begin{array}{l}\text { Uninnervated skeletal muscle, heart, } \\
\text { brain }\end{array}$ & $\begin{array}{l}\text { Breast cancer [81, 82], arrhythmia [83], Brugada syndrome [84], } \\
\text { angiogenic disorders [85] }\end{array}$ \\
\hline $\mathrm{Na}_{\mathrm{v}} 1.6$ & $S C N 8 A$ & CNS, PNS, heart & Epilepsy [86], cervical cancer [87] \\
\hline $\mathrm{Na}_{\mathrm{v}} 1.7$ & SCN9A & $\begin{array}{l}\text { PNS, neuroendocrine cells, sensory } \\
\text { neurons }\end{array}$ & Angiogenic disorders [85], paroxysmal extreme pain disorder [88] \\
\hline $\mathrm{Na}_{\mathrm{v}} 1.8$ & SCN10A & Sensory neurons & Prostate cancer [89], cardiac arrhythmia [90], MS [90, 91] \\
\hline $\mathrm{Na}_{\mathrm{v}} 1.9$ & SCN11A & Sensory neurons & Congenital insensitivity [92], cold-aggravated pain [93] \\
\hline $\mathrm{Na}_{\mathrm{x}}$ & $\begin{array}{l}\text { SCN6A, } \\
\text { SCN7A }\end{array}$ & $\begin{array}{l}\text { Heart, uterus, skeletal muscle, } \\
\text { astrocytes, DRG }\end{array}$ & Atopic dermatitis [94], hypertension [95] \\
\hline \multicolumn{4}{|c|}{ (B) The $\beta$ subunits } \\
\hline$\beta 1$ & $S C N 1 B$ & Heart, skeletal muscle, CNS, glia, PNS & Epilepsy [96], cardiac arrhythmia [97], cancer [98] \\
\hline$\beta 1 \mathrm{~A}(\beta 1 \mathrm{~B})$ & $S C N 1 B$ & $\begin{array}{l}\text { Heart, skeletal muscle, adrenal gland, } \\
\text { PNS }\end{array}$ & Epilepsy [96] \\
\hline$\beta 2$ & $S C N 2 B$ & CNS, PNS, heart, glia & Altered pain response [59], MS [99] \\
\hline$\beta 3$ & $S C N 3 B$ & CNS, adrenal gland, kidney, PNS & Cancer $[98]$ \\
\hline$\beta 4$ & $S C N 4 B$ & Heart, skeletal muscle, CNS, PNS & Huntington's disease [100] \\
\hline
\end{tabular}

$C N S$ central nervous system, $M S$ multiple sclerosis, $P N S$ peripheral nervous system, $C B H$ chronic brain hypoperfusion

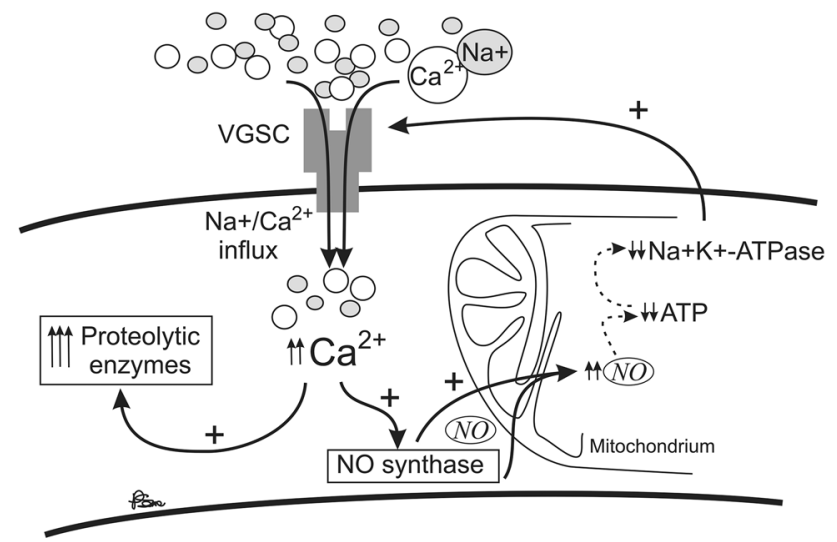

Fig. 1 Positive feedback loop of $\mathrm{Na} / \mathrm{Ca}$ influx to the neuron cell with a potential damaging effect in multiple sclerosis (VGSC voltage-gated sodium channel, $N O$ nitric oxide, ATP adenosine triphosphate, $\mathrm{Na}^{+} \mathrm{K}^{+}$-ATPase sodium-potassium adenosine triphosphatase)

\section{Sodium chloride intake and MS}

High intake of sodium chloride is currently considered to be a potentially important factor influencing the onset of MS. Changes in eating habits that have occurred in recent decades in developed countries may account for an increase in incidence of MS and other autoimmune diseases [122]. Today's typical Western diet includes more sodium chloride than it was in the past [123]. Therefore, popular processed meals, such as "fast food", contain approximately 100 times more sodium chloride than homemade meals [124, 125]. Increased hypertonicity can stimulate the immune system [126], and furthermore, superior sodium chloride uptake can affect the innate immune system [127].

Recent studies have demonstrated the importance of interleukin-17 (IL-17)-induced CD4+ Th17 cell population in autoimmune diseases [128]. Kleinewietfield et al. showed that the addition of a modest amount of $\mathrm{NaCl}$ (40 mM) to a culture of differentiating Th17 cells caused a roughly logarithmic augmentation of IL-17A in naïve CD4 cells in vitro and this process was mediated by $\mathrm{p} 38$ /MAPK, NFAT5, and SGK [122]. Moreover, high-salt concentration results in growth of pathogenic phenotype of Th17 cells $[122,129,130]$. Thus, the change in eating habits that includes a high amount of salt may contribute to the recent increase in MS incidence through the induction of pathogenic Th17 cells [122, 126, 128]. The Th17 cells induced by high-salt concentration upregulate the production of pro-inflammatory cytokines GM-CSF, TNF $\alpha$, IL-2, IL-9, several chemokines [131, 132], and CCR6 [133], which are essential for the autoimmune function of Th17 cells. Higher $\mathrm{Na}^{+}$concentration, such as that between 160 and $250 \mathrm{mM}$, in the interstitium and lymphoid tissue and significantly lower concentration of $\mathrm{Na}^{+}$in plasma, approximately $140 \mathrm{mM}$, are likely to be the mechanism for 
decreasing the inflammatory response in the blood while favoring immune activation in lymphoid tissues or with migration of cells into tissue [127, 134]. Otherwise, diet rich in salt can affect the severity of the disease. Kleinewietfeld et al. showed that mice fed salty meals developed deterioration of EAE, with an increase in Th17 cell number and augmented infiltration of Th17 cells into the CNS [122]. Moreover, in an observational trial on 122 MS patients, Farez et al. demonstrated that the disease exacerbation rate was 2.75 -fold in participants with medium salt intake (2-4.8 g/day) (95\% CI 1.3-5.8) and 9.95fold in participants with high sodium intake $(4.8 \mathrm{~g} /$ day or more) (95\% CI 1.4-11.2) compared with the low-intake group (under $2 \mathrm{~g} /$ day) [135]. This finding may be due to the fact that sodium concentration is tightly regulated within narrow limits regardless of large variations in sodium consumption, due to its importance in general metabolism [136]. The renin-angiotensin-aldosterone system (RAAS), which is a major regulator of blood pressure, also significantly affects autoimmunity in many diseases which include MS and its animal model-EAE. Han et al. showed that peptides related to the RAAS are present in CNS lesions of MS patients [137]. Sodium chloride, among many other physiological effects, modulates the renin-angiotensin system [138]. Interestingly, the activation of renin and angiotensin has been implicated in the pathogenesis of EAE [139]. Furthermore, increases in systolic blood pressure similar to those observed with high-salt consumption have recently been shown to be associated with the disruption of white matter integrity in young normotensive individuals [140]. In addition, Platten et al. demonstrated an increase in the expression of angiotensin receptor 1 (AT1R) in lymph node cells, indicating that AT1R is activated in antigen-specific $T$ cells during the peripheral immune response to autoantigens. In addition, angiotensin II (AII) binding was augmented in PeriodateLysine-Paraformaldehyde (PLP)-activated CD4 $+\mathrm{T}$ cells and to a lesser extent in activated CD11b + monocytes. Immunization with PLP139-151 led to an induction of AII in CD4 + T cells, CD11b + monocytes, and to an increase in serum AII levels, demonstrating that the RAAS is activated in peripheral immune cells. Pretreatment of mice immunized with PLP139-151 with the angiotensin converting enzyme (ACE) inhibitor lisinopril \{N2-[(S)-1-carboxy-3-phenylpropyl]-L-lysyl-L-proline $\}$ or the AT1R antagonist candesartan (3-\{[2'-(2 H -tetrazol-5-yl)biphenyl-4-yl]methyl \}-2-ethoxy-3 H -benzo[d]imidazole-4-carboxylic acid) resulted in suppression of Th1 and Th17 cytokine release and up-regulation of immunosuppressive cytokines, such as IL-10 and transforming growth factor- $\beta$ (TGF- $\beta$ ) [141]. Probable impact of high sodium diet on immune functions in MS patients was presented in Fig. 2.

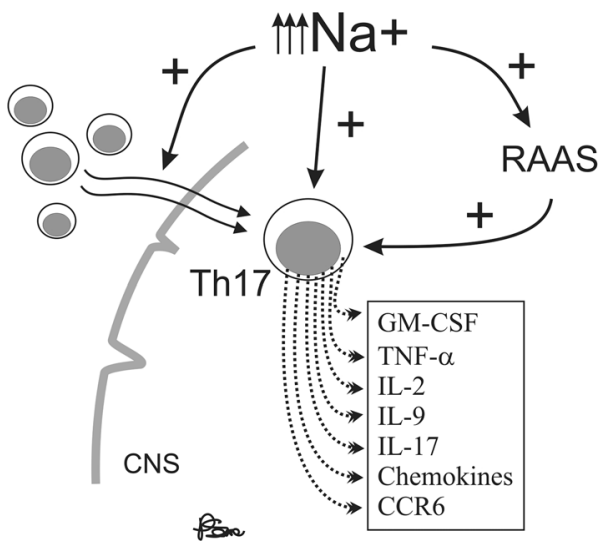

Fig. 2 Probable impact of high sodium diet on immune functions in multiple sclerosis patients (CNS central nervous system, RAAS reninangiotensin-aldosterone system)

Hucke et al. revealed a multidirectional activity of sodium chloride-rich diet in both humans and mice. Sodium chloride-rich diet promotes CNS autoimmunity, increases macrophage responses, skews the balance towards a pro-inflammatory M1 phenotype in macrophages, alters MAPK signaling in macrophages, and induces a pro-inflammatory phenotype in human monocytes [142]. In addition, Yi et al. demonstrated that highsalt intake promotes an increase in human serum monocytes, which play a pivotal role in the development of various immunological diseases [143]. Furthermore, Jörg et al. showed that a high-salt diet in the early phase of neuroinflammation mainly acts on Th17 cells and is independent of myeloid cells. This finding can help elucidate the impact of a high-salt diet on the emergence and course of autoimmune diseases [144]. Krementsov et al. demonstrated an increase in blood-brain barrier permeability and brain pathology in mice as a consequence of a high-salt diet, but did not demonstrate augmentation of Th17 or Th1 responses. Moreover, this study showed that the effects of dietary sodium on autoimmune neuroinflammation are sexspecific, genetically dependent, and CNS-mediated [145]. Furthermore, Zhou et al. demonstrated that a short-term increase in dietary salt intake could induce the expansion of $\mathrm{CD} 14++\mathrm{CD} 16+$ monocytes, as well as an increase in monocyte platelet aggregates (MPAs), which might be the cellular basis of high-salt-induced end organ inflammation and potential thromboembolic risk, independent of changes in blood pressure [146]. In addition, Hernandez et al. reported that excess dietary sodium intake lowers immunosuppressive actions of human and murine Foxp3+ Tregs in vitro and in vivo and is associated with increased Treg IFN $\gamma$ secretion in vivo [147]. Data concerning the immunological effects of sodium chloride intake are shown in Table 2. 
Table 2 Immunological effects of sodium chloride intake

\begin{tabular}{|c|c|c|c|c|}
\hline Examined subjects & $\begin{array}{l}\text { Time } \\
\text { (days) }\end{array}$ & Sodium intake & Observed effects & \\
\hline C57BL/6J mice & 20 & $\mathrm{Na}^{+}$-rich diet & $\begin{array}{l}\text { Increase in Th17 cells proliferation } \\
\text { Exacerbation of EAE }\end{array}$ & [121] \\
\hline $\begin{array}{l}\text { Human and rabbit } \\
\text { PBMC }\end{array}$ & - & $\begin{array}{l}\mathrm{Na}^{+} \text {hipertonic medium } \\
25-30 \mathrm{mM} \text { (in vitro) }\end{array}$ & $\begin{array}{l}\mathrm{T} \text { cell proliferation was doubled in } 25 \mathrm{mM} \text { medium } \\
\text { Increased hypertonicity ( }>40 \mathrm{mM} \text { in human cells; }>80 \mathrm{mM} \text { in rabbit } \\
\text { cells) caused progressive Suppression of proliferation } \\
\text { monocyte functions augmentation }\end{array}$ & [126] \\
\hline $\begin{array}{l}\mathrm{Cd} 4 \mathrm{Cre} \text { Sgk1 } \mathrm{fl} / \mathrm{fl} \\
\text { mice and WT mice }\end{array}$ & 21 & High-salt diet & $\begin{array}{l}\text { Increase in EAE severity in WT mice, but not in SGK1-deficient mice } \\
\text { Increase of Th17 cells in mLN and CNS of WT mice, but not in SGK1- } \\
\text { deficient mice } \\
\text { Increase in IFN production by T cells in the CNS in WT mice } \\
\text { Increase in IL-17 synthesis by CD4+ T cells }\end{array}$ & [130] \\
\hline RRMS patients & 720 & $\begin{array}{l}\text { Dietary } 2-4.8 \mathrm{~g} / \text { day of } \\
\mathrm{Na}^{+} \text {intake }\end{array}$ & $\begin{array}{l}\text { Increase in exacerbation rate ( } 2-4 \text { fold }) \text { in patients with medium or high } \\
\text { sodium diet } \\
\text { Increase in the risk of developing a new MRI lesions in high } \mathrm{Na}^{+} \text {diet } \\
\text { patients }\end{array}$ & [135] \\
\hline C57BL/6J mice & 50 & $\mathrm{Na}^{+}$-rich diet & $\begin{array}{l}\text { Increase in murine Th17 and Th1 cells } \\
\text { Increase in IL-17A and IFN- } \gamma \text { secretion }\end{array}$ & [144] \\
\hline $\begin{array}{l}\text { C57BL6/J mice and } \\
\text { SJL/JCrHsd mice }\end{array}$ & - & High-salt diet & $\begin{array}{l}\text { Exacerbation of disease in } \mathrm{M} \text { and } \mathrm{F} \text { of C57BL6/J mice but only in } \mathrm{F} \text { of } \\
\text { SJL/JCrHsd mice } \\
\text { No influence on C57BL6/J mice carrying a } 129 / \mathrm{Sv} \text {-derived interval on } \\
\text { chromosome } 17 \\
\text { No influence on Th17 or Th1 cells } \\
\text { Increase in blood-brain barrier permeability and brain pathologies }\end{array}$ & [145] \\
\hline $\begin{array}{l}\text { Foxp3-GFP reporter } \\
\text { mice }\end{array}$ & 21 & $\mathrm{Na}^{+}$-rich diet & $\begin{array}{l}\text { Induction of Th1-type phenotype } \\
\text { Impairement in Treg function (IFN } \gamma \text {-dependent) }\end{array}$ & [147] \\
\hline Healthy human & 205 & Dietary $\mathrm{NaCl}$ reduction & $\begin{array}{l}\text { Decrease in monocytes counts } \\
\text { Decrease in IL-6 (30\%), IL-23 (90\%) and IL-17 concentration } \\
\text { Increase in IL-10 level (threefold) } \\
\text { Slightly decrease in VEGF-C serum concentration }\end{array}$ & \\
\hline Healthy human & 17 & High-to-low $\mathrm{NaCl}$ diet & $\begin{array}{l}\text { Increase in } \mathrm{CD} 14++ \text { and } \mathrm{CD} 16+\text { monocytes proliferation } \\
\text { Increase in intracellular ROS production }\end{array}$ & \\
\hline
\end{tabular}

$E A E$ experimental autoimmune encephalomyelitis, $P B M C$ peripheral blood mononuclear cells, $R O S$ reactive oxygen species

In conclusion, recent reports have demonstrated a potential pro-inflammatory role of excess sodium chloride intake in the pathogenesis of autoimmune and neurodegenerative diseases, both in vitro and in vivo, although the outcomes of these studies are not unanimous. Nevertheless, the current knowledge suggests that a low-salt diet ( $<5 \mathrm{~g} /$ day) might be beneficial in the prevention and treatment of autoimmune diseases, including MS.

\section{Compliance with ethical standards}

Conflict of interest The authors report no conflict of interest. The authors alone are responsible for the content and writing of this paper.

Open Access This article is distributed under the terms of the Creative Commons Attribution 4.0 International License (http://creative commons.org/licenses/by/4.0/), which permits unrestricted use, distribution, and reproduction in any medium, provided you give appropriate credit to the original author(s) and the source, provide a link to the Creative Commons license, and indicate if changes were made.

\section{References}

1. Moghadasi AN, Pourmand S, Sharifian M et al (2016) Behavioral neurology of multiple sclerosis and autoimmune encephalopathies. Neurol Clin 34(1):17-31

2. Mandia D, Ferraro OE, Nosari G et al (2014) Environmental factors and multiple sclerosis severity: a descriptive study. Int J Environ Res Public Health 11(6):6417-6432

3. Ascherio A, Munger KL, Lennette ET et al (2001) Epstein-Barr virus antibodies and risk of multiple sclerosis: a prospective study. JAMA 286(24):3083-3088

4. Farrell RA, Antony D, Wall GR et al (2009) Humoral immune response to EBV in multiple sclerosis is associated with disease activity on MRI. Neurology 73(1):32-38 
5. Ramroodi N, Niazi AA, Sanadgol N et al (2013) Evaluation of reactive Epstein-Barr Virus (EBV) in Iranian patient with different subtypes of multiple sclerosis (MS). Braz J Infect Dis 17(2):156-163

6. Pierrot-Deseilligny C (2009) Clinical implications of a possible role of vitamin $\mathrm{D}$ in multiple sclerosis. $\mathrm{J}$ Neurol 256(9):1468-1479

7. Cline J (2012) Calcium and vitamin d metabolism, deficiency, and excess. Top Companion Anim Med 27(4):159-164

8. Holmøy T, Torkildsen $\varnothing$, Myhr KM et al (2012) Vitamin D supplementation and monitoring in multiple sclerosis: who, when and wherefore. Acta Neurol Scand Suppl 195:63-69

9. Steffensen LH, Brustad M, Kampman MT (2013) What is needed to keep persons with multiple sclerosis vitamin D-sufficient throughout the year? J Neurol 260(1):182-188

10. Kampman MT, Steffensen LH, Mellgren SI et al (2012) Effect of vitamin D3 supplementation on relapses, disease progression, and measures of function in persons with multiple sclerosis: exploratory outcomes from a double-blind randomised controlled trial. Mult Scler 18(8):1144-1151

11. Stein MS, Liu Y, Gray OM et al (2011) A randomized trial of high-dose vitamin D2 in relapsing-remitting multiple sclerosis. Neurology 77(17):1611-1618

12. Hedström AK, Olsson T, Alfredsson L (2016) Smoking is a major preventable risk factor for multiple sclerosis. Mult Scler 22(8):1021-1026

13. Ramanujam R, Hedström AK, Manouchehrinia A et al (2015) Effect of smoking cessation on multiple sclerosis prognosis. JAMA Neurol 72(10):1117-1123

14. Kvistad SS, Myhr KM, Holmøy T et al (2015) Body mass index influence interferon-betatreatment response in multiple sclerosis. J Neuroimmunol 288:92-97

15. Sloka S, Silva C, Pryse-Phillips W et al (2011) A quantitative analysis of suspected environmental causes of MS. Can J Neurol Sci 38(1):98-105

16. Bäärnhielm M, Hedström AK, Kockum I et al (2012) Sunlight is associated with decreased multiple sclerosis risk: no interaction with human leukocyte antigen-DRB1*15. Eur J Neurol 19(7):955-962

17. Marrie RA (2004) Environmental risk factors in multiple sclerosis aetiology. Lancet Neurol 3(12):709-718

18. Pugliatti M, Sotgiu S, Rosati G (2002) The worldwide prevalence of multiple sclerosis. Clin Neurol Neurosurg 104(3):182-191

19. Munger KL, Levin LI, O'Reilly EJ et al (2011) Anti-EpsteinBarr virus antibodies as serological markers of multiple sclerosis: a prospective study among United States military personnel. Mult Scler 17(10):1185-1193

20. Villoslada P, Juste C, Tintore $M$ et al (2003) The immune response against herpesvirus is more prominent in the early stages of MS. Neurology 60(12):1944-1948

21. Yea C, Tellier R, Chong P et al (2013) Canadian pediatric demyelinating disease network. Epstein-Barr virus in oral shedding of children with multiple sclerosis. Neurology 81(16):1392-1399

22. Buljevac D, Flach HZ, Hop WC et al (2002) Prospective study on the relationship between infections and multiple sclerosis exacerbations. Brain 125(Pt5):952-960

23. Versini M, Jeandel PY, Rosenthal E et al (2014) Obesity in autoimmune diseases: not a passive bystander. Autoimmun Rev 13(9):981-1000

24. Cao H (2014) Adipocytokines in obesity and metabolic disease. J Endocrinol 220(2):T47-T59

25. Oliveira SR, Simão AN, Kallaur AP et al (2014) Disability in patients with multiple sclerosis: influence of insulin resistance, adiposity, and oxidative stress. Nutrition 30(3):268-273
26. Simpson S Jr, Blizzard L, Otahal P et al (2011) Latitude is significantly associated with the prevalence of multiple sclerosis: a meta-analysis. J Neurol Neurosurg Psychiatry 82(10):1132-1141

27. Harbo HF, Utsi E, Lorentzen AR et al (2007) Low frequency of the disease-associated DRB1*15-DQB $1 * 06$ haplotype may contribute to the low prevalence of multiple sclerosis in Sami. Tissue Antigens 69(4):299-304

28. Kingwell E, Marriott JJ, Jetté N et al (2013) Incidence and prevalence of multiple sclerosis in Europe: a systematic review. BMC Neurol 13:128

29. Kantarci O, Wingerchuk D (2006) Epidemiology and natural history of multiple sclerosis: new insights. Curr Opin Neurol 19(3):248-254

30. Coo H, Aronson KJ (2004) A systematic review of several potential non-genetic risk factors for multiple sclerosis. Neuroepidemiology 23(1-2):1-12

31. Smolders J, Damoiseaux J, Menheere P et al (2008) Vitamin D as an immune modulator in multiple sclerosis, a review. J Neuroimmunol 194(1-2):7-17

32. Pantzaris MC, Loukaides GN, Ntzani EE et al (2013) A novel oral nutraceutical formula of omega-3 and omega- 6 fatty acids with vitamins (PLP10) in relapsing remitting multiple sclerosis: a randomised, double-blind, placebo-controlled proof-of-concept clinical trial. BMJ Open 3(4):e002170

33. Torkildsen O, Wergeland S, Bakke S et al (2012) $\omega-3$ fatty acid treatment in multiple sclerosis (OFAMS Study): a randomized, double-blind, placebo-controlled trial. Arch Neurol 69(8):1044-1051

34. Khalili M, Azimi A, Izadi V et al (2014) Does lipoic acid consumption affect the cytokine profile in multiple sclerosis patients: a double-blind, placebo-controlled, randomized clinical trial. Neuroimmunomodulation 21(6):291-296

35. Vergelli M, Olivotto J, Castigli E et al (1997) Immunosuppressive activity of 13-cis-retinoic acid in rats: aspects of pharmacokinetics and pharmacodynamics. Immunopharmacology 37(2-3):191-197

36. Hall JA, Grainger JR, Spencer SP et al (2011) The role of retinoic acid in tolerance and immunity. Immunity 35(1):13-22

37. Bitarafan S, Saboor-Yaraghi A, Sahraian MA et al (2016) Effect of vitamin A supplementation on fatigue and depression in multiple sclerosis patients: a double-blind placebo-controlled clinical trial. Iran J Allergy Asthma Immunol 15(1):13-19

38. Storoni M, Plant GT (2015) The therapeutic potential of the ketogenic diet in treating progressive multiple sclerosis. Mult Scler Int 2015:681289

39. Allen BG, Bhatia SK, Anderson CM et al (2014) Ketogenic diets as an adjuvant cancer therapy: history and potential mechanism. Redox Biol 2:963-970

40. Kim do Y, Hao J, Liu R et al (2012) Inflammation-mediated memory dysfunction and effects of a ketogenic diet in a murine model of multiple sclerosis. PLoS One 7(5):e35476

41. Malin SK, Cotugna N, Fang CS (2008) Effect of creatine supplementation on muscle capacity in individuals with multiple sclerosis. J Diet Suppl 5(1):20-32

42. Swank RL, Goodwin J (2003) Review of MS patient survival on a Swank low saturated fat diet. Nutrition 19(2):161-162

43. Riccio P, Rossano R (2015) Nutrition facts in multiple sclerosis. ASN Neuro 7(1):1759091414568185. doi:10.1177/ 1759091414568185

44. Plemel JR, Juzwik CA, Benson CA et al (2015) Over-thecounter anti-oxidant therapies for use in multiple sclerosis: a systematic review. Mult Scler 21(12):1485-1495

45. Abdolahi M, Yavari P, Honarvar NM et al (2015) Molecular mechanisms of the action of vitamin A in Th17/Treg axis in multiple sclerosis. J Mol Neurosci 57(4):605-613 
46. Bitarafan S, Saboor-Yaraghi A, Sahraian MA et al (2015) Impact of vitamin A supplementation on disease progression in patients with multiple sclerosis. Arch Iran Med 18(7):435-440

47. Hille B (1978) Ionic channels in excitable membranes. Current problems and biophysical approaches. Biophys J 22(2):283-294

48. Hodgkin AL, Huxley AF (1952) A quantitative description of membrane current and its application to conduction and excitation in nerve. J Physiol 117:500-544

49. Barres BA, Chun LL, Corey DP (1990) Ion channels in vertebrate glia. Annu Rev Neurosci 13:441-474

50. Gautron S, Dos Santos G, Pinto-Henrique D et al (1992) The glial voltage-gated sodium channel: cell- and tissue-specific mRNA expression. Proc Natl Acad Sci USA 89(15):7272-7276

51. Gosling M, Harley SL, Turner RJ et al (1998) Human saphenous vein endothelial cells express a tetrodotoxin-resistant, voltage-gated sodium current. J Biol Chem 273(33):21084-21090

52. Diss JK, Fraser SP, Djamgoz MB (2004) Voltage-gated $\mathrm{Na}^{+}$ channels: multiplicity of expression, plasticity, functional implications and pathophysiological aspects. Eur Biophys J 33(3):180-193

53. Káradóttir R, Hamilton NB, Bakiri Y et al (2008) Spiking and nonspiking classes of oligodendrocyte precursor glia in CNS white matter. Nat Neurosci 11(4):450-456

54. Zhao P, Barr TP, Hou Q et al (2008) Voltage-gated sodium channel expression in rat and human epidermal keratinocytes: evidence for a role in pain. Pain 139(1):90-105

55. Lopez-Santiago LF, Meadows LS, Ernst SJ et al (2007) Sodium channel Scn $1 \mathrm{~b}$ null mice exhibit prolonged QT and RR intervals. J Mol Cell Cardiol 43:636-647

56. Wallace RH, Wang DW, Singh R et al (1998) Febrile seizures and generalized epilepsy associated with a mutation in the $\mathrm{Na}^{+}$channel beta1 subunit gene SCN1B. Nat Genet 19:366-370

57. Audenaert D, Claes L, Ceulemans B et al (2003) A deletion in SCN1B is associated with febrile seizures and early-onset absence epilepsy. Neurology 61:854-856

58. Scheffer IE, Harkin LA, Grinton BE et al (2007) Temporal lobe epilepsy and GEFS+ phenotypes associated with SCN1B mutations. Brain 130(Pt 1):100-109

59. Lopez-Santiago LF, Pertin M, Morisod X et al (2006) Sodium channel beta2 subunits regulate tetrodotoxin-sensitive sodium channels in small dorsal root ganglion neurons and modulate the response to pain. J Neurosci 26:7984-7994

60. Cummins TR, Sheets PL, Waxman SG (2007) The roles of sodium channels in nociception: implications for mechanisms of pain. Pain 131:243-257

61. Fontaine B, Khurana TS, Hoffman EP et al (1990) Hyperkalemic periodic paralysis and the adult muscle sodium channel alpha-subunit gene. Science 250:1000-1002

62. Waxman SG (2007) Channel, neuronal and clinical function in sodium channelopathies: from genotype to phenotype. Nat Neurosci 10:405-409

63. Dichgans M, Freilinger T, Eckstein G et al (2005) Mutation in the neuronal voltage-gated sodium channel SCN1A in familial hemiplegic migraine. Lancet 366:371-377

64. Waxman SG (2006) Axonal conduction and injury in multiple sclerosis: the role of sodium channels. Nat Rev Neurosci 7:932-941

65. Fraser SP, Diss JK, Chioni AM et al (2005) Voltage-gated sodium channel expression and potentiation of human breast cancer metastasis. Clin Cancer Res 11:5381-5389

66. Brackenbury WJ, Isom LL (2008) Voltage-gated $\mathrm{Na}^{+}$channels: potential for beta subunits as therapeutic targets. Expert Opin Ther Targets 12(9):1191-1203

67. Brackenbury WJ, Djamgoz MB, Isom LL (2008) An emerging role for voltage-gated $\mathrm{Na}^{+}$channels in cellular migration: regulation of central nervous system development and potentiation of invasive cancers. Neuroscientist 14(6):571-583

68. Roy ML, Narahashi T (1992) Differential properties of tetrodotoxin-sensitive and tetrodotoxin-resistant sodium channels in rat dorsal root ganglion neurons. J Neurosci 12(6):2104-2111

69. Ikeda SR, Schofield GG, Weight FF (1986) $\mathrm{Na}^{+}$and $\mathrm{Ca}^{2+}$ currents of acutely isolated adult rat nodose ganglion cells. J Neurophysiol 55(3):527-539

70. Sun LH, Yan ML, Hu XL et al (2015) MicroRNA-9 induces defective trafficking of Nav1.1 and Nav1.2 by targeting Nav $\beta 2$ protein coding region in rat with chronic brain hypoperfusion. Mol Neurodegener 10:36

71. Ogiwara I, Miyamoto H, Morita N et al (2007) Nav1.1 localizes to axons of parvalbumin-positive inhibitory interneurons: a circuit basis for epileptic seizures in mice carrying an Scn1a gene mutation. J Neurosci 27(22):5903-5914

72. Catterall WA, Kalume F, Oakley JC (2010) NaV1.1 channels and epilepsy. J Physiol 588(Pt 11):1849-1859

73. Howell KB, McMahon JM, Carvill GL et al (2015) SCN2A encephalopathy: a major cause of epilepsy of infancy with migrating focal seizures. Neurology 85(11):958-966

74. Gazina EV, Leaw BT, Richards KL et al (2015) 'Neonatal' Nav1.2 reduces neuronal excitability and affects seizure susceptibility and behaviour. Hum Mol Genet 24(5):1457-1468

75. Dhalla AK, Yang M, Ning Y et al (2014) Blockade of $\mathrm{Na}^{+-}$ channels in pancreatic $\alpha$-cells has antidiabetic effects. Diabetes 63(10):3545-3556

76. Lin CR, Chen KH, Yang $\mathrm{CH}$ et al (2014) Intrathecal miR-183 delivery suppresses mechanical allodynia in mononeuropathic rats. Eur J Neurosci 39(10):1682-1689

77. Tan AM, Samad OA, Dib-Hajj SD et al (2015) Virus-mediated knockdown of Nav1.3 in dorsal root ganglia of STZ-induced diabetic rats alleviates tactile allodynia. Mol Med 21:544-552

78. Zang Y, He XH, Xin WJ et al (2010) Inhibition of NF-kappaB prevents mechanical allodynia induced by spinal ventral root transection and suppresses the re-expression of Nav1.3 in DRG neurons in vivo and in vitro. Brain Res 1363:151-158

79. Bissay V, Van Malderen SC, Keymolen K et al (2016) SCN4A variants and Brugada syndrome: phenotypic and genotypic overlap between cardiac and skeletal muscle sodium channelopathies. Eur J Hum Genet 24(3):400-407

80. Cannon SC (2015) Channelopathies of skeletal muscle excitability. Compr Physiol 5(2):761-790

81. Nelson M, Yang M, Millican-Slater R et al (2015) Nav1.5 regulates breast tumor growth and metastatic dissemination in vivo. Oncotarget 6(32):32914-32929

82. Mohammed FH, Khajah MA, Yang M et al (2016) Blockade of voltage-gated sodium channels inhibits invasion of endocrineresistant breast cancer cells. Int J Oncol 48(1):73-83

83. Musa H, Kline CF, Sturm AC et al (2015) SCN5A variant that blocks fibroblast growth factor homologous factor regulation causes human arrhythmia. Proc Natl Acad Sci USA 112(40):12528-12533

84. Tan BY, Yong RY, Barajas-Martinez H et al (2016) A Brugada syndrome proband with compound heterozygote SCN5A mutations identified from a Chinese family in Singapore. Europace 18(6):897-904

85. Andrikopoulos P, Fraser SP, Patterson L et al (2011) Angiogenic functions of voltage-gated $\mathrm{Na}^{+}$channels in human endothelial cells: modulation of vascular endothelial growth factor (VEGF) signaling. J Biol Chem 286(19):16846-16860

86. O'Brien JE, Meisler MH (2013) Sodium channel SCN8A (Nav1.6): properties and de novo mutations in epileptic encephalopathy and intellectual disability. Front Genet 4:213

87. Hernandez-Plata E, Ortiz CS, Marquina-Castillo B et al (2012) Overexpression of $\mathrm{NaV} 1.6$ channels is associated with the 
invasion capacity of human cervical cancer. Int $\mathrm{J}$ Cancer 130(9):2013-2023

88. Fertleman CR, Ferrie CD, Aicardi J et al (2007) Paroxysmal extreme pain disorder (previously familial rectal pain syndrome). Neurology 69(6):586-595

89. Suy S, Hansen TP, Auto HD et al. (2012) Expression of voltagegated sodium channel $\mathrm{Na}(\mathrm{v}) 1.8$ in human prostate cancer is associated with high histological grade. J Clin Exp Oncol. doi:10.4172/2324-9110.1000102

90. Han C, Huang J, Waxman SG (2016) Sodium channel Nav1.8: emerging links to human disease. Neurology 86(5):473-483

91. Roostaei T, Sadaghiani S, Park MT et al (2016) Channelopathyrelated SCN10A gene variants predict cerebellar dysfunction in multiple sclerosis. Neurology 86(5):410-417

92. Woods CG, Babiker MO, Horrocks I et al (2015) The phenotype of congenital insensitivity to pain due to the NaV1.9 variant $p$. L811P. Eur J Hum Genet 23(10): 1434

93. Leipold E, Hanson-Kahn A, Frick M et al (2015) Cold-aggravated pain in humans caused by a hyperactive NaV1.9 channel mutant. Nat Commun 6:10049

94. Xu W, Hong SJ, Zhong A et al (2015) Sodium channel Nax is a regulator in epithelial sodium homeostasis. Sci Transl Med 7(312):312ra177

95. Noda M, Hiyama TY (2015) Sodium sensing in the brain. Pflug Arch 467(3):465-474

96. Scheffer IE, Harkin LA, Grinton BE et al (2007) Temporal lobe epilepsy and GEFS+ phenotypes associated with SCN1B mutations. Brain 130(Pt 1):100-109

97. Watanabe H, Darbar D, Kaiser DW et al (2009) Mutations in sodium channel beta1- and beta2-subunits associated with atrial fibrillation. Circ Arrhythm Electrophysiol 2:268-275

98. Roger S, Rollin J, Barascu A et al (2007) Voltage-gated sodium channels potentiate the invasive capacities of human non-smallcell lung cancer cell lines. Int J Biochem Cell Biol 39:774-786

99. O'Malley HA, Shreiner AB, Chen GH et al (2009) Loss of $\mathrm{Na}^{+}$ channel beta2 subunits is neuroprotective in a mouse model of multiple sclerosis. Mol Cell Neurosci 40(2):143-155

100. Oyama F, Miyazaki H, Sakamoto N et al (2006) Sodium channel beta4 subunit: down-regulation and possible involvement in neuritic degeneration in Huntington's disease transgenic mice. J Neurochem 98(2):518-529

101. Isom LL, De Jongh KS, Patton DE et al (1992) Primary structure and functional expression of the beta 1 subunit of the rat brain sodium channel. Science 256(5058):839-842

102. Isom LL, Ragsdale DS, De Jongh KS et al (1995) Structure and function of the beta 2 subunit of brain sodium channels, a transmembrane glycoprotein with a CAM motif. Cell 83(3):433-442

103. Morgan K, Stevens EB, Shah B et al (2003) beta 3: an additional auxiliary subunit of the voltage-sensitive sodium channel that modulates channel gating with distinct kinetics. Proc Natl Acad Sci USA 97(5):2308-2313

104. Yu FH, Westenbroek RE, Silos-Santiago I et al (2003) Sodium channel beta4, a new disulfide-linked auxiliary subunit with similarity to beta2. J Neurosci 23(20):7577-7585

105. Black JA, Westenbroek R, Ransom BR et al (1994) Type II sodium channels in spinal cord astrocytes in situ: immunocytochemical observations. Glia 12:219-227

106. Reese KA, Caldwell JH (1999) Immunocytochemical localization of NaCh6 in cultured spinal cord astrocytes. Glia 26:92-96

107. Black JA, Dib-Hajj S, Cohen S et al (1998) Glial cells have heart: $\mathrm{rH} 1 \mathrm{Na}^{+}$channel mRNA and protein in spinal cord astrocytes. Glia 23:200-208

108. Barres BA, Chun LL, Corey DP (1989) Glial and neuronal forms of the voltage-dependent sodium channel: characteristics and cell-type distribution. Neuron 2:1375-1388
109. Herzog RI, Liu C, Waxman SG et al (2003) Calmodulin binds to the $\mathrm{C}$ terminus of sodium channels Nav1.4 and Nav1.6 and differentially modulates their functional properties. J Neurosci 23:8261-8270

110. Kapoor R (2008) Sodium channel blockers and neuroprotection in multiple sclerosis using lamotrigine. J Neurolog Sci 274(1-2):54-56

111. Nikolaeva MA, Mukherjee B, Stys PK (2005) $\mathrm{Na}^{+}$-dependent sources of intra-axonal $\mathrm{Ca}^{2+}$ release in rat optic nerve during in vitro chemical ischemia. J Neurosci 25:9960-9967

112. Waxman SG (2008) Mechanisms of disease: sodium channels and neuroprotection in multiple sclerosis current status. Nat Clin Pract Neurol 4(3):159-169

113. Pappalardo LW, Samad OA, Black JA et al (2014) Voltagegated sodium channel Nav 1.5 contributes to astrogliosis in an in vitro model of glial injury via reverse $\mathrm{Na}^{+} / \mathrm{Ca}^{2+}$ exchange. Glia 62(7):1162-1175

114. Bechtold DA, Kapoor R, Smith KJ (2004) Axonal protection using flecainide in experimental autoimmune encephalomyelitis. Ann Neurol 55(5):607-616

115. Morsali D, Bechtold D, Lee W et al (2013) Safinamide and flecainide protect axons and reduce microglial activation in models of multiple sclerosis. Brain 136(Pt 4):1067-1082

116. Lo AC, Black JA, Waxman SG (2002) Neuroprotection of axons with phenytoin in experimental allergic encephalomyelitis. Neuroreport 13:1909-1912

117. Bechtold DA, Miller SJ, Dawson AC et al (2006) Axonal protection achieved in a model of multiple sclerosis using lamotrigine. J Neurol 253:1542-1551

118. Craner MJ, Damarjian TG, Liu S et al (2005) Sodium channels contribute to microglia/macrophage activation and function in EAE and MS. Glia 49(2):220-229

119. Counihan TJ, Duignan JA, Gormley G et al (2014) Does longterm partial sodium channel blockade alter disease progression in MS? Evidence from a retrospective study. Ir J Med Sci 183(1):117-121

120. Gnanapavan S, Grant D, Morant S et al (2013) Biomarker report from the phase II lamotrigine trial in secondary progressive MSneurofilament as a surrogate of disease progression. PLoS One 8(8):e70019

121. Kapoor R, Furby J, Hayton T et al (2010) Lamotrigine for neuroprotection in secondary progressive multiple sclerosis: a randomised, double-blind, placebo-controlled, parallel-group trial. Lancet Neurol 9(7):681-688

122. Kleinewietfeld M, Manzel A, Titze J et al (2013) Sodium chloride drives autoimmune disease by the induction of pathogenic TH17 cells. Nature 496(7446):518-522

123. McGuire S (2010) Institute of Medicine. 2010. Strategies to reduce sodium intake in the United States. The National Academies Press, Washington. Adv Nutr 1:49-50

124. Appel LJ, Frohlich ED, Hall JE et al (2011) The importance of population-wide sodium reduction as a means to prevent cardiovascular disease and stroke: a call to action from the American Heart Association. Circulation 123:1138-1143

125. Brown IJ, Tzoulaki I, Candeias V et al (2009) Salt intakes around the world: implications for public health. Int J Epidemiol 38:791-813

126. Junger WG, Liu FC, Loomis WH et al (1994) Hypertonic saline enhances cellular immune function. Circ Shock 42:190-196

127. Machnik A, Neuhofer W, Jantsch et al (2009) Macrophages regulate salt-dependent volume and blood pressure by a vascular endothelial growth factor-C-dependent buffering mechanism. Nat Med 15(5):545-552

128. Korn T, Bettelli E, Oukka M et al (2009) IL-17 and Th17 Cells. Annu Rev Immunol 27:485-517 
129. Ghoreschi K, Laurence A, Yang XP et al (2010) Generation of pathogenic $\mathrm{T}(\mathrm{H}) 17$ cells in the absence of TGF-beta signalling. Nature 467:967-971

130. Wu C, Yosef N, Thalhamer T et al (2013) Induction of pathogenic TH17 cells by inducible salt-sensing kinase SGK1. Nature 496(7446):513-517

131. Codarri L, Gyülvészi G, Tosevski V et al (2011) RORgammat drives production of the cytokine GM-CSF in helper T cells, which is essential for the effector phase of autoimmune neuroinflammation. Nat Immunol 12:560-567

132. El-Behi M, Ciric B, Dai H et al (2011) The encephalitogenicity of $\mathrm{T}(\mathrm{H}) 17$ cells is dependent on IL-1- and IL-23-induced production of the cytokine GM-CSF. Nat Immunol 12:568-575

133. Reboldi A, Coisne C, Baumjohann D et al (2009) C-C chemokine receptor 6-regulated entry of TH-17 cells into the CNS through the choroid plexus is required for the initiation of EAE. Nat Immunol 10:514-523

134. Go WY, Liu X, Roti MA et al (2004) NFAT5/TonEBP mutant mice define osmotic stress as acritical feature of the lymphoid microenvironment. Proc Natl Acad Sci USA 101:10673-10678

135. Farez MF, Fiol MP, Gaitán MI et al (2015) Sodium intake is associated with increased disease activity in multiple sclerosis. J Neurol Neurosurg Psychiatry 86(1):26-31

136. Fulgoni VL 3rd (2007) Limitations of data on fluid intake. J Am Coll Nutr 26(5 Suppl):588S-591S

137. Han MH, Hwang SI, Roy DB et al (2008) Proteomic analysis of active multiple sclerosis lesions reveals therapeutic targets. Nature 451(7182):1076-1081

138. Goodfriend TL, Elliott ME, Catt KJ (1996) Angiotensin receptors and their antagonists. N Engl J Med 334:1649-1654

139. Stegbauer J, Lee DH, Seubert S et al (2009) Role of the reninangiotensin system in autoimmune inflammation of the central nervous system. Proc Natl Acad Sci USA 106:14942-14947
140. Maillard P, Seshadri S, Beiser A et al (2012) Effects of systolic blood pressure on white-matter integrity in young adults in the Framingham Heart Study: a cross-sectional study. Lancet Neurol 11:1039-1047

141. Platten M, Youssef S, Hur EM et al (2009) Blocking angiotensin-converting enzyme induces potent regulatory $\mathrm{T}$ cells and modulates TH1- and TH17-mediated autoimmunity. Proc Natl Acad Sci USA 106(35):14948-14953

142. Hucke S, Eschborn M, Liebmann M et al (2016) Sodium chloride promotes pro-inflammatory macrophage polarization thereby aggravating CNS autoimmunity. J Autoimmun 67:90-101

143. Yi B, Titze J, Rykova M et al (2015) Effects of dietary salt levels on monocytic cells and immune responses in healthy human subjects: a longitudinal study. Transl Res 166(1):103-110

144. Jörg S, Kissel J, Manzel A et al (2016) High salt drives Th17 responses in experimental autoimmune encephalomyelitis without impacting myeloid dendritic cells. Exp Neurol 279:212-222

145. Krementsov DN, Case LK, Hickey WF et al (2015) Exacerbation of autoimmune neuroinflammation by dietary sodium is genetically controlled and sex specific. FASEB J 29(8):3446-3457

146. Zhou X, Zhang L, Ji WJ et al (2013) Variation in dietary salt intake induces coordinated dynamics of monocyte subsets and monocyte-platelet aggregates in humans: implications in end organ inflammation. In: Zirlik A (ed) PLoS One 8(4):e60332

147. Hernandez AL, Kitz A, Wu C et al (2015) Sodium chloride inhibits the suppressive function of FOXP3+ regulatory T cells. J Clin Investig 125(11):4212-4222 